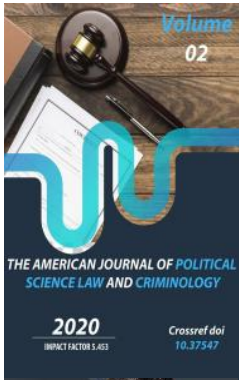

Journal Website: http://usajournalshub.c om/index,php/tajpslc

Copyright: Original content from this work may be used under the terms of the creative commons attributes 4.0 licence.

\section{Violence As An Apparatus Of Intellectual Skirmishes: Reconnoiter The Occurrences In Northeastern Nigeria And Appraise The Permissible Arrangement}

\author{
Adekunbi Mosheim \\ Department of Jurisprudence and Public Law, School of Law and Security Studies, Nigeria \\ Abington Nzeribe \\ Department of Private and Commercial Law, School of Law and Security Studies, Nigeria
}

\title{
ABSTRACT
}

This article audits and inspects the utilization of violence as a apparatus of intellectual oppression in the North Eastern piece of Nigeria. The examination will look at the reasons for illegal intimidation in North Eastern Nigeria and why ladies like to hush up about being violenceed by intellectual oppressors. The issue of allowing absolution to fear based oppressors and whether they will even now be arraigned will be investigated. All the more along these lines, existing lawful structure that tends to the arraignment of violence during and after outfitted clash will be explored. It is suggested that the National Assembly ought to order an Act that will expressly manage the wrongdoing of violence during and after equipped clashes in Nigeria particularly to deal with arising and unanticipated conditions.

\section{KEYWORDS}

Rape, Sexual Terrorism, Boko Haram, and Victims

\section{INTRODUCTION}

Worldwide, intellectual skirmishes are turning into a family unit word as there is no nation that is totally exculpated from its impact. Globalization has definitely impacted the development of intellectual skirmishes as the occasion in one portion of the globe has immediate or a circuitous result on others.
This explain why war, savagery and different types of trans-public political mercilessness are from multiple points of view more compromising today than any other time in recent memory as regular citizen setback has been on the high. 
It is anyway hard to concoct a solitary definition for the expression "intellectual skirmishes" which has advanced after some time, however its political, strict, and philosophical objectives have basically never showed signs of change. Violence is one of the most slippery yet least recognized basic freedoms infringements on the planet. Violence has extreme short and long haul consequences for the survivors, culprits, families, networks, ethnic gatherings, district, and the capacity of the country to turn out to be entire indeed. The brutality infiltrates and slices through substance just as spirits, and the fruitful recuperating of both isn't ensured. Genuine confusions with labor, feminine cycle, pee, and fecal evacuation are normal. Numerous casualties are delivered sterile because of the injury, tasks, or scar tissue [7] . Notwithstanding causing injury, violence expands ladies' drawn out danger of various unintended pregnancy, explicitly sent diseases, and unfavorable pregnancy results. Truth be told, the kids conceived from moms who are casualties of violence during illegal intimidation are demonized in the in the Internally Displaced Persons Camp in the Northeastern piece of Nigeria.

\section{Lawful structure on violence in Nigeria}

It is essential to take note of that sexual viciousness in outfitted clash is just a piece of the more extensive issue of sexual savagery against ladies. Albeit in Nigeria there is no single Act that tends to sexual brutality against ladies and young ladies during strife. The nearest Acts that can be said to handle the issue of violence in Nigeria is The Violence against Persons Act, 2016, The Criminal Code Act and The Penal Code Act.

\section{DISCUSSION}

There is requirement for government to establish an Act that will unequivocally manage the wrongdoing of violence during and after furnished clashes in Nigeria particularly to deal with arising and unanticipated conditions. The VAPP Act, the Penal Code and the Criminal Code don't have arrangements for sexual intellectual oppression during furnished clash. The schooling of adolescents should be focused on by government as this is the vital apparatus to break the pattern of destitution in the northern area of Nigeria. Instruction outfits the adolescents with essential ability whether in farming, business and different fields of human charm our own. There should be round-the - check security in schools to shield school young ladies from snatching, violence and constrained marriage by Boko Haram intellectual militant gathering.

The public authority (state and public) ought to team up with global giver organization to give money move awards to help moms and their children who are in inside uprooted homes in the north eastern piece of Nigeria. This will go far in building certainty and consolation on destitute moms to send back their youngsters to schools.

\section{CONCLUSION}

Violence is the most successive kind of brutality utilized against ladies during savage clashes and frequently happens close to state intellectual oppression as a procedure to disrespect, ethnically purify, or quiet rivals. Violence is a plague with wide-coming to and enduring impacts for its casualties. It is without question a training which needs concentrated thought focused on anticipation, arraignment and mending for survivors.

Despite the fact that administration is satisfactorily reacting to forestall violence and ensure casualties as the public authority is by and by winning the fight against Boko Haram 
and step by step information on government troops protecting scores of snatched ladies and young ladies however a great deal actually should be finished by the public authority to give mental and clinical consideration to survivors of sexual intellectual skirmishes or different infringement as separated from the Chibok young ladies that got away from Boko Haram bondage, none of different casualties of kidnapping or different infringement had gotten any government supported emotional wellness or clinical consideration. Like different types of rape, reacting to sexual illegal intimidation requires criminal equity, clinical, mental and social activities.

\section{REFERENCES}

1. Barnes K. Illegal intimidation Today, Frank Cass Publishers, 2012.

2. William S. Illegal intimidation: The Present Threat in Context. 2016.

3. Inside Terrorism: Columbia University Press, 2016, 56. 